\title{
Pola Pengawasan Kepala Seksi Penyelenggaraan Haji dan Umrah dalam Meningkatkan Kinerja Pegawai
}

\author{
Syalsabila Ramadhini", Syamsudin RS, \& Asep Iwan Setiawan \\ Jurusan Manajemen Dakwah, Fakultas Dakwah dan Komunikasi, \\ UIN Sunan Gunung Djati, Bandung \\ *Email:syalsabila@student.uinsgd.ac.id
}

\begin{abstract}
ABSTRAK
Penelitian ini bertujuan untuk mengetahui bagaimana proses pengawasan yang dilakukan oleh kepala seksi Penyelenggaraan Haji dan Umrah Kementerian Agama Kota Sukabumi terhadap pegawai dalam pelaksanaan program kerja dan bagaimana tindakan yang dilakukan oleh kepala seksi dalam meningkatkan kinerja pegawainya. Metode penelitian ini menggunakan metode deskriptif Teknik pengumpulan data dalam penelitian ini yaitu melalui observasi, wawancara, dan studi dokumentasi. Adapun analisis data dilakukan melalui penafsiran logika yang dihubungkan dengan konteks Manajemen Dakwah. Hasil penelitian menunjukkan bahwa: Pertama, standar pengawasan yang ditetapkan di Seksi Penyelenggaraan Haji dan Umrah; Kedua, tindakan evaluasi yang dilakukan oleh Kepala Seksi Penyelenggaraan Haji dan Umrah dalam meningkatkan kinerja pegawai; Ketiga, tindakan perbaikan (corrective) yang dilakukan oleh Kepala Seksi Penyelenggaraan Haji dan Umrah dalam meningkatkan kinerja pegawai. Secara umum penelitian ini dapat disimpulkan bahwa pola pengawasan yang dilakukan oleh Kepala Seksi Penyelenggaraan Haji dan Umrah ini sudah tepat, dengan adanya proses evaluasi dan tindakan perbaikan sehingga program kerja yang telah ditetapkan dapat berjalan dengan efektif dan lancar.
\end{abstract}

Kata Kunci : Pengawasan; Penyelenggaraan Haji dan Umrah; Kinerja Pegawai

\section{ABSTRACT}

This research aims to find out how the supervision process conducted by the head section of Haij and Umrah Implementation of the Ministry of Religious Affairs Sukabumi to employees in the implementation of work programs and how the actions performed by the head section in improving employee performance. This research method using descriptive method Data collection techniques in this study is through observation, interviews, and documentation studies. The data analysis is done through the interpretation of logic that is connected with the context of Da'wah Management. The results showed that: First, the supervisory standards set out in the Haij and Umrah Section Implementation Section; Second, evaluation actions undertaken by Section Head of Haij and Umrah Implementation in improving the performance of employees; Third, corrective action conducted by the Head of Section of Hajj and Umrah Implementation in improving the performance of employees. In general, this research can be concluded that the supervision pattern 
Syalsabila Ramadhini, Syamsuin RS, \& Asep Iwan Setiawan

conducted by the Head of Section of Haij and Umrah Implementation is correct, with the evaluation process and corrective action so that the work program that has been set can run effectively and smoothly.

Keywords: Control, Haji and Umrah Implementation, Employee Performance

\section{PENDAHULUAN}

Ibadah haji adalah rukun Islam kelima. Kewajiban untuk berhaji minimal sekali dalam seumur hidup itu dibebankan hanya kepada seorang muslim yang mampu dalam arti luas, yaitu mampu secara jasmani maupun secara rohani. Ibadah haji juga merupakan kewajiban yang harus dilaksanakan oleh setiap umat Islam yang memenuhi syarat istitaah, baik secara finansial, fisik maupun mental. Haji pada hakikatnya merupakan aktifitas suci yang pelaksanaannya diwajibkan oleh Allah kepada seluruh umat Islam yang telah mencapai istitho'a (mampu), disebut aktifitas suci karena seluruh rangkaian kegiatannya adalah ibadah (Syari'ati, Haji, 2000:1). Indonesia sebagai salah satu negara yang memiliki jumlah penduduk beragama Islam terbesar di dunia selalu menyelenggarakan haji setiap tahunnya. Dalam Undang-Undang Nomor 13 Tahun 2008 tentang Penyelenggaraan Ibadah Haji, mengatur mengenai rangkaian kegiatan pengelolaan pelaksanaan ibadah haji yang meliputi pembinaan, pelayanan, dan perlindungan jamaah haji yaitu untuk memberikan pembinaan, pelayanan, dan perlindungan bagi jamaah haji. Adapun tujuan dari penyelenggaraan ibadah haji yaitu untuk memberikan pembinaan, pelayanan, dan perlindungan yang sebaik-baiknya bagi jemaah haji sehingga jemaah haji dapat menunaikan ibadahnya sesuai dengan ketentuan ajaran agama Islam. Penyelenggaraan Ibadah haji dilaksanakan berdasarakan asas keadilan, profesionalitas, dan akuntabilitas dengan prinsip nirlaba (Undang-Undang Nomor 13 Tahun 2008 tentang Penyelenggaraan ibadah haji pasal 1 ayat 2 dan pasal 3).

Pelaksanaan ibadah haji di Indonesia secara nasional menjadi wewenang Kementerian Agama (Kemenag). Dalam kewenangan tersebut juga terkandung tanggung jawab yang besar karena dalam pelaksanaan ibadah haji diperlukan pelayanan yang baik. Pelayanan ibadah haji tidak hanya menyangkut kesejahteraan lahir dan batin jamaah haji, namun menyangkut nama baik dan martabat bangsa Indonesia di luar negeri, khususnya di Arab Saudi. Mengingat pelaksanaannya bersifat massal dan berlangsung dalam jangka waktu yang terbatas, maka penyelenggaraan ibadah haji memerlukan manajemen yang baik, agar penyelenggaraan ibadah haji tersebut dapat berjalan dengan tertib, aman, dan lancar (Dirjend. Pelayanan Haji dan Umroh, 2010:11).

Sejauh ini yang peneliti dapatkan pada saat melakukan wawancara awal dengan pihak Kemenag Kota Sukabumi bahwa pengawasan mengenai pelaksanaan proses penyelenggaraan ibadah haji ini dinilai belum maksimal. Namun dalam prakteknya Undang-Undang Nomor 13 Tahun 2008 belum menjawab harapan masyarakat karena masih terdapat permasalahanpermasalahan yang terjadi dilapangan salah satunya terkait dengan kurangnya pembinaan melalui manasik haji yang hanya menitikberatkan pada ibadah hajinya 
saja tanpa memperhatikan aspek penguasaan lapangan. Berangkat dari permasalahan ini maka dibutuhkan pengawasan yang baik dan benar pada saat akan dilaksanakannya penyelenggaraan ibadah haji. Maka dari itu perlunya pimpinan yang bisa mengelola lembaga yang dinaunginya agar tingkat kedisiplinan pegawai lebih maksimal dalam mememahi jobdescnya dan pimpinan juga perlu kiranya mengetahui lebih jauh bagaimana manajemen pelayanan ibadah haji, yang artinya sistem manajemen yang sejatinya dapat menjalankan fungsi-fungsi merencana, mengorganisasi, mengarahkan dan mengawasi kegiatan penyelenggaraan haji demi terlaksananya penyelenggaraan ibadah haji yang aman, lancar, dan berjalan dengan baik (Pasal 5 Undang-Undang No 17 Tahun 1999 tentang tentang Penyelenggaran Ibadah Haji). Penyelenggaraan ibadah haji akan berjalan dengan baik apabila didukung dengan pengawasan yang baik agar dapat mencapai tujuan yang diharapkan. Dalam aktifitas penyelenggaraan ibadah haji, pengawasan sangatlah dibutuhkan. Pengawasan mempunyai kedudukan penting dalam suatu lembaga. Tanpa pengawasan yang baik kegiatan-kegiatan suatu lembaga yang dilaksanakan tidak dapat dicapai tujuannya. Jadi, secara teoritis keberhasilan suatu lembaga terletak pada kemampuan pimpinan lembaga beserta staf pengurus lembaga lainnya yang secara operasional melakukan pengelolaan terhadap organisasi untuk mencapai suatu tujuan tertentu.

Setiap lembaga pasti memerlukan pegawai sebagai tenaga yang menjalankan setiap aktivitas yang ada dalam lembaga tersebut. Seorang pegawai merupakan aset terpenting yang memiliki pengaruh sangat besar terhadap kesuksesan sebuah lembaga atau kesuksesan sebuah kegiatan. Tanpa mesin canggih, lembaga dapat terus beroperasi secara manual, akan tetapi tanpa pegawai, lembaga tidak akan dapat berjalan sama sekali. Maka dari itu pada saat penyelenggaraan ibadah haji lembaga membutuhkan pegawai yang dapat membantu mencapai tujuan dan membutuhkan pegawai yang dapat mengerti tentang proses penyelenggaraan ibadah haji serta dapat memahami setiap aspek yang dibutuhkan oleh jamaah haji agar jamaah haji tidak tersesat karena tidak memahami alur perjalanan ibadah haji pada saat praktik dilapangan.

Berdasarkan data diatas, kita dapat melihat bahwa dalam penyelanggaraan ibadah haji dibutuhkan persiapan yang matang dan dibantu dengan manajemen yang baik yang dilakukan oleh setiap unsur manajemen (men/manusia) baik itu pemimpin maupun pegawai agar tidak terjadi lagi permasalahan yang begitu kompleks pada saat eksekusi dilapangan. Maka dari itu, penulis tertarik untuk meneliti tentang "Pola Pengawasan Kepala Seksi Penyelenggaraan Haji Dan Umrah Dalam Meningkatkan Kinerja Pegawai (Studi Deskriptif pada Kementrian Agama Kota Sukabumi)".

Penelitian ini dilakukan di Kementrian Agama Kota Sukabumi Bidang Haji dan Umroh yang beralamat di Jl. Taman Bahagia No. 20, Benteng, Warudoyong, Kota Sukabumi-43132 Provinsi Jawa Barat, pengambilan lokasi di daerah tersebut mengingat besarnya kemungkinan penelitian dapat dilaksanakan yaitu dengan melihat data-data yang dibutuhkan dalam penelitian ini tersedia dan untuk 
mengumpulkan data-data juga tidak terlalu sulit. Dilihat dari pertimbangan kesesuaian dengan latar belakang akademik penyusun, penelitian ini tepat dilaksanakan mengingat ada kolerasi antara penyusum yang sedang studi tentang manajemen dakwah dengan pengambilan judul dan objek penelitian tersebut.

Adapun pertanyaan pada penelitian ini yaitu: 1) Apa saja standar pengawasaan yang ditetapkan di Seksi Penyelenggaraan Haji dan Umrah Kementerian Agama Kota Sukabumi. 2) Bagaimana tindakan evaluasi yang dilakukan Kepala Seksi Penyelenggaraan Haji dan Umrah Kementerian Agama Kota Sukabumi. 3) Bagaimana tindakan perbaikan (corrective) yang di lakukan Kepala Seksi Penyelenggaraan Haji dan Umrah Kementerian Agama Kota Sukabumi. Metode penelitian yang digunakan oleh peneliti yaitu metode penelitian deskriptif Metode deskriptif yaitu suatu rumusan masalah yang memandu penelitian untuk mengeksplorasi atau memotret situasi sosial yang akan diteliti secara menyeluruh, luas, dan mendalam. Metode ini bertujuan untuk melukiskan secara sistematis fakta atau karakteristik populasi tertentu atau bidang tertentu secara faktual dan cermat. Dalam proses pengumpulan datanya ia lebih menitikberatkan pada observasi lapangan dan suasana ilmiah, dengan mengamati gejala-gejala, mencatat, mengategorikan, dan sedapat mungkin menghindari pengaruh kehadirannya untuk menjaga keaslian gejala yang diamati. (Jalaludin Rakhmat, 1985: 34-35). Dengan menggunakan metode ini peneliti akan menganalisis hasil pengumpulan data melalui observasi dan wawancara dengan kepala seksi Penyelenggaraan Haji dan Umrah Kementerian Agama Kota Sukabumi.

\section{LANDASAN TEORITIS}

Pola mengandung arti gambar yang dipakai untuk contoh batik atau tenun; ragi; sari; potongan kertas yang dipakai sebagai contoh dalam membuat baju dan sebaginya; model; sistem; cara kerja: -permainan; -pemerintahan; bentuk (struktur) yang tetap: -kalimat; kombinasi sifat kecenderungan membantuk karangan yang taat asas yang bersifat khas dalam puisi - adalah bentuk sajak yang dinyatakan dengan bunyi, gerak, kata ataupun (KBBI, 2001:884)

Fungsi Pengendalian (controling) adalah fungsi terakhir dari proses manajemen. Fungsi ini sangat penting dan menentukan pelaksanaan proses manajemen, oleh karena itu harus dilakukan dengan sebpaik-baiknya. Pengendalian adalah kegiatan mengendalikan semua karyawan agar mentaati peraturan-peraturan perusahaan dan bekerja sesuai dengan rencana. Apabila terdapat penyimpangan atau kesalahan, diadakan tindakan perbaikan dan penyempurnaan rencana (Hasibuan, 2006:22). Untuk lebih jelasnya dibawah ini akan dikemukakan beberapa pengertian pengawasan oleh beberapa pakar manajemen. Menurut G.R. Terry yang dikutip oleh Hasibuan (2011:242) "Pengendalian dapat didefinisikan sebagai proses penentuan, apa yang harus dicapai yaitu standar, apa yang sedang dilakukan yaitu pelaksanaan, menilai pelaksanaan, menilai pelaksanaan dan apabila perlu melakukan perbaikan- 
perbaikan, sehingga pelaksanaan sesuai dengan rencana yaitu selaras dengan standar".

Teori pengawasan menurut Prajudi Atosudirjo yang dikutip oleh Hamzah Yaqub (1984:110) menatakan bahwa pengawasan itu terjadi atas segala aktifitas dan tindakan untuk mengamankan rencana dan keputusan yang telah dibuat dan sedang dilakukan atau dengan kata lain, pengawasan adalah keseluruhan daripada aktifitas dan tindakan-tindakan (measurnes dan metrelegen) kita untuk menjamin atau membuat supaya semua pelaksanaan berlangsung serta berhasil sesuai dengan apa yang diharapkan dan direncanakan, diputuskan dan diakomodasikan Menurut Harold Koontz yang dikutip oleh Hasibuan (2011:242) Pengendalian adalah pengukuran dan perbaikan terhadap pelaksanaan kerja bawahan, agar rencanarencana yang telah dibuat untuk mencapai tujuan-tujuan perusahaan dapat terselenggara.

Tujuan dari pengawasan adalah agar hasil pelaksanaan pekerjaan diperoleh secara budaya guna (efisien) dan berhasil guna (efektif) sesuai dengan rencana yang telah ditentukan sebelumnya (Handayaningrat, 1982:143). Tujuan pengendalian juga yaitu supaya proses pelaksanaan dilakukan sesuai dengan ketentuan-ketentuan dari rencana, melakukan tindakan perbaikan (corrective), jika terdapat penyimpangan-penyimpangan (deviasi), dan supaya tujuan yang dihasilkan sesuai dengan rencananya.

Pengendalian bukan hanya untuk mencari kesalahan-kesalahan, tetapi berusaha untuk menghindari terjadinya kesalahan-kesalahan serta memperbaikinya jika terdapat kesalahan-kesalahan. Jadi pengendalian dilakukan sebelum proses, saat proses, dan setelah proses, yakni hingga hasil akhir diketahui. Dalam merealisasikan tujuan organisasi atau lembaga, pimpinan organisasi menempuh cara melalui langkah-langkah pelaksanaan atau yang sering disebut sebagai suatu proses, mulai dari merencanaan, mengorganisir, mengarahkan dan mengawasi. Menurut Manullang (2008:184) proses pengawasan yang berobjekkan apapun terdiri dari 3 (tiga) tahap, yaitu: 1) Menetapkan alat pengukur (standar), standar adalah satu kriteria tentang hasil yang diinginkan atau peristiwa yang diharapkan dengan mana manajer dapat membandingkan subskuensi kegiatan, pelaksanaan dan hasil kerja atau perubahan yang terjadi dalam pencapaian tujuan. 2) Mengadakan penilaian (evaluasi), fase kedua dalam proses proses pengawasan adalah menilai atau mengevaluasi. Maksudnya membandingkan hasil pekerjaan bawahan, dengan alat ukur (standar) yang sudah ditentukan. Pekerjaan bawahan dapat diketahui melalui berbagai cara, yakni dari laporan tertulis yang disusun bawahan, baik laporan rutin maupun laporan istimewa dan langsung mengunjungi bawahan untuk menanyakan hasil pekerjaannya atau bawahan dipanggil untuk memberi laporan lisan. 3) Mengadakan tindakan perbaikan (corrective action), fase terakhir ini hanya dilaksanakan, bila pada fase sebelumnya dipastikan telah terjadi penyimpangan. Dengan tindakan perbaikan diartikan, tindakan yang diambil untuk menyesuaikan hasil pekerjaan nyata yang menyimpang agar sesuai dengan standar atau rencana yang telah ditentukan sebelumnya. Untuk dapat 
Syalsabila Ramadhini, Syamsuin RS, \& Asep Iwan Setiawan

melaksanakan tindakan perbaikan, maka haruslah dianalisis apa yang menyebabkan terjadinya perbedaan itu.

Seorang manajer harus mempunyai berbagai cara untuk memastikan bahwa semua fungsi manajemen dilaksanakan dengan baik. Hal ini dapat diketahui melalui proses kontrol atau pengawasan. Cara-cara pengendalian atau pengawasan ini dilakukan sebagai berikut: 1) Pengawasan Langsung, pengawasan langsung adalah pengawasan yang dilakukan sendiri secara langsung oleh seorang manajer. Manajer memeriksa pekerjaan yang sedang dilakukan untuk mengetahui apakah dikerjakan dengan benar dan hasil-hasilnya sesuai dnegan yang dikehendakinya. 2) Pengawasan Tidak Langsung, pengawasan tidak langsung adalah pengawasan jarak jauh, artinya dengan melalui laporan yang diberikan oleh bawahan. Laporan ini dapat berupa lisan atau tulisan tentang pelaksanaan pekerjaan dan hasil-hasil yang telah dicapai. 3) Pengawasan Berdasarkan Kekecualian, pengawasan ini dikhususkan untuk kesalahan-kesaahan yang luar biasa dari hasil atau standar yang diharapkan. Pengendalian semacam ini dilakukan dengan cara kombinasi langsung dan tidak langsung oleh manajer.

Penyelenggaraan ibadah haji merupakan salah satu icon Kementerian Agama. Bagi sebagian orang, keberhasilan kinerja Kementerian Agama kerap hanya diukur sejauhmana Kementerian ini sukses menyelenggarakan pengelolaan ibadah tahunan tersebut. Haji adalah salah satu rukun Islam yang kelima yang diwajibkan Allah SWT kepada orang-orang yang mampu menunaiknannya, yakni memliki kesanggupan biaya serta sehat jasmani dan rohani untuk melakukan perintah tersebut. Kewajiban ibdah haji hanya sekali seumur hdup. Kewajiban ini baru disyariatkan pada tahun ke-6 hijriyah, setelah Rasulullah SAW hijrah ke Madinah. Nabi sendiri hanya sekali mengajarkan haji yang kemudian dikenal dengan sebutan Haji Wada'. Tak lama setelah itu, beliau wafat.

Beberapa keutamaan dan hikmah ibadah haji, diantaranya: 1) Mengajarkan ibadah haji adalah pekerjaan yang sangat mulia dan sangat terpuji, 2) Ibadah haji memberi kesan dan pesan terhadap perjalanan kehidupan seseorang., 3) Ibadah haji merupakan manifestasi ketundukan kepada Allah SWT, 4) Melaksanakan ibadah haji merupakan ungkapan syukur atas nikmat harta dan kesehatan, 5) Haji menempa jiwa agar memiliki semangat juang tinggi. Segala kesulitan yang dihadapi sejak dari tanah air hingga ditanah suci dan kembali lagi ke tanah air merupakan tantangan yang harus dihadapi seorang haji yang dengan itu, ia belajar sabar, tabah, kuat, disiplin, dan terdorong berakhlak mulia, 6) Haji dapat menjadi pemersatu antar umat Islam sedunia, 7) Para jamaah haji adalah delegasi Allah SWT.

Haji merupakan sebuah ritual ibadah istimewa yang tidak semua orang berkesempatan untuk melakukannya. Haji pada hakikatnya merupakan aktifitas suci yang pelaksanaannya diwajibkan oleh Allah kepada seluruh umat Islam yang telah mencapai istitho'a (mampu), disebut aktifitas suci karena seluruh rangkaian kegiatannya adalah ibadah. (Ali Syari'ati, Haji, 2000:1). Haji adalah suatu ibadah yang dilakukan dengan mengunjungi Ka'bah dan dilakukan pada waktu tertentu dengan syarat-syarat yang telah ditentukan atau ditetapkan. Kesemuanya itu 
dilakukan dalam rangka menaati perintah Allah SWT., dan mencapai rida-Nya. Ibadah haji tidak dilakukan di sembarang tempat, waktu, dan perbuatan. Jika tidak dilakukan pada tempat, waktu, dan tidak memenuhi ketentuannya, bukanlah haji.

Tentang syarat-syarat wajibnya haji itu menurut Tata Sukayat (2016:13) ialah : (1) Islam, (2) Baligh, (3) Berakal, (4) Merdeka, (5) Kuasa (mampu), (6) Sehat badannya, orang sakit, atau lemah bisa diwakilkan kepada orang lain apabila ia mempunyai cukup harta, (7) Ada kendaraan yang dapat mengangkut untuk pergi ke Makkah, (8) Keamanan dalam perjalan terjamin, (9) Memiliki bekal yang cukup bagi dirinya dan keluarganya sampai kembali dari haji, (10) Bagi wakita, harus bersama muhrim atau wanita lain uang mempunyai muhrim.

Kinerja merupakan salah satu elemen penting yang harus terdapat dalam sebuah perusahaan dengan tingkat yang ditetapkan sebagai acuan. Kinerja adalah suatu tampilan keadaan secara utuh atas prestasi yang dipengaruhi oleh kegiatan operasional perusahaan dalam manfaat sumber daya yang dimiliki. Perilaku merupakan perilaku nyata yang dikumpulkan setiap orang sebagai prestasi kerja yang dihasilkan karyawan sesuai dengan peran dalam perusahaan (Rivai dan Sagala, 2009:604).

Menurut Robert L. Mathis da John Jackson (2002:81) mengatakan bahwa penilaian kinerja merupakan proses mengevaluasi seberapa baik karyawan mengerjakan pekerjaan mereka ketika dibandingkan dengan satu set standar, dan kemudian mengomunikasikan informasi tersebut. Penilaian tersebut nantinya akan menjadi bahan masukan yang berarti dalam menilai kinerja yang dilakukan dan selanjutnya dapat dilakukan perbaikan, atau yang biasa disebut perbaikan yang berkelanjutan.

Menurut John Whitmore yang dikutip oleh Lilis Sulastri (2016:162) mengatakan bahwa kinerja dalah pelaksanaan fungsi-fungsi yang dituntut dari seorang atau suatu perbuatan, suatu prestasi, suatu pameran umum keterampilan”. Kinerja merupakan suatu kondisi yang harus diketahui dan dikonfirmasikan kepada pihak tertentu untuk mengetahui tingkat pencapaian hasil suatu instansi dihubungkan dengan visi yang diemban suatu organisasi atau perusahaan serta mengetahui dampak positif dan negative dari suatu kebijakan operasional.

Keberhasilan sebuah organisasi dalam mencapai visi dan misi sangat tergantung pada kualitas Sumber Daya Manusia yang dimiliki. Kualitas SDM tersebut dapat ditunjukkan oleh kompetensi, skills, dan kemampuan karyawan dalam mencipatakan kualitas kerja yang profesional dalam membangun teamwork dalam organisasi. Sehingga ada kemungkinan dalam organisasi terdapat dua jenis karyawan yang berkualitas, yang dapat dilihat dari kinerja dan keefektifan mereka dalam melaksanakan tugas (Sulastri, 2016:164).

\section{HASIL DAN PEMBAHASAN}

Penelitian ini dilakukan di Kementerian Agama Kota Sukabumi, kelurahan warudoyong. Rute menuju Kementerian Agama Kota Sukabumi ini dapat ditempuh menggunakan kendaraan roda dua maupun roda empat, apabila dari 
arah Kota Sukabumi yaitu arahnya ke barat menuju daerah nyomplong kemudian ke arah TPU Taman Bahagia. Lokasi Kementerian Agama Kota Sukabumi ini cukup mudah ditemukan karena berada di area pemakaman Taman Bahagia.

Kementerian Agama Kota Sukabumi merupakan instansi vertikal kementerian agama, dimana Kementerian Agama Kota Sukabumi ini mendukung pelaksanaan tugas dan fungsi Kementerian Agama dalam meningkatkan pelayanan pemerintah terhadap masyarakat dalam memberikan pembinaan keagamaan. Dalam upaya memberikan pelayanan, para pegawai harus melaksanakan tugas pokok dan fungsi Kementerian Agama dalam wilayah Kota/Kabupaten berdasarkan kebijakan Kepala Kantor Wilayah Kementerian Agama dan ketentuan perundang-undangan yang berlaku. Para pekerja di Kementerian Agama Kota Sukabumi ini mayoritasnya adalah ASN atau Pegawai Negeri Sipil (PNS) maka dari itu setiap Pegawai Negeri Sipil harus memiliki pakta integritas agar para pegawai dapat bertanggung jawab terhadap tugasnya masing-masing dan dengan adanya pakta integritas ini dapat mengantisipasi tindakan korupsi, kolusi, dan nepotisme yang mungkin sewaktu-waktu dapat dilakukan oleh para pegawai, selain memiliki pakta integritas para pegawai disini juga harus mengacu pada kode etik pns.

Hasil dari penelitian yang dilakukan di Kementerian Agama Kota Sukabumi khususnya di seksi penyelenggaraan haji dan umrah, peneliti mendapatkan hasil bahwa pengawasan yang dilakukan oleh kepala seksi penyelenggaraan haji dan umrah ini sangat baik, sehingga dapat membawa dampak baik dalam proses peningkatan kinerja pegawainya, kepala seksi penyelenggaraan haji dan umrah ini selalu dekat dengan para pegawainya sehingga para pegawainya menjadi semangat dalam menjalankan tugas mereka, karena prioritas utama dari mereka itu adalah pemberian pelayanan prima kepada para jamaah serta mengimplementasikan kode etik dan menjalankan apa yang tertulis pada pakta integritas mereka sebagai seorang pegawai negeri sipil.

Pada dasarnya setiap lembaga atau organisasi selalu melaksanakan proses pengawasan karena pengawasan ini merupakan tahapan-tahapan di dalam melaksanakan kegiatan program kerja pada suatu lembaga. Proses pengawasan yang baik akan memastikan tujuan yang telah ditetapkan dari awal kepengurusan atau setelah pembentukan lembaga dapat tercapai. Kementerian Agama Kota Sukabumi khususnya Seksi Penyelenggaraan Haji dan Umrah memerlukan pengawasan yang dilakukan oleh kepala seksi dalam pencapaian tujuan, pengawasan dapat dianggap sebagai sebuah pengukuran dan perbaikan terhadap pelaksanaan kerja yang dilakukan oleh pegawai agar rencana-rencana yang telah dibuat untuk pencapaian tujuan dapat terselenggara. Saat melakukan pengawasan Kepala Seksi PHU bukan untuk mencari kesalahan-kesalahan pegawai tetapi berusaha untuk menghindari terjadinya kesalahan serta berusaja memperbaiki jika terdapat kesalahan. Jadi pengawasan yang dilakukan oleh Kepala Seksi PHU itu dilakukan sebelum pelaksanaan kegiatan, pada saat pelaksanaan kegiatan dan setelah pelaksanaan kegiatan. 
Proses pelaksanaan pengawasan yang dilakukan oleh Kepala Seksi PHU ini mengacu pada tahapan-tahapan pengawasan, dimana tahapan-tahapan tersebut dilakukan agar proses pengawasan berjalan efektif dan efisien. Adapun tahapan pelaksanaan pengawasan yang dilakukan oleh Kepala Seksi Penyelenggaraan Haji dan Umrah yaitu:

\section{Penetapan Alat Ukur (Standar)}

Standar adalah satu kriteria tentang hasil yang diinginkan atau peristiwa yang diharapkan dengan mana manajer dapat membandingkan subskuensi kegiatan, pelaksanaan dan hasil kerja atau perubahan yang terjadi dalam pencapaian tujuan (Manullang, 2008:184). Alat ukur sangatlah penting keberadaannya dalam melaksanakan pekerjaan disebuah lembaga, sebab dengan adanya alat ukur ini pemimpin dapat mengukur dan mengetahui kinerja bawahannya.. Pada tahapan ini seorang pemimpin menentukan dan menetapkan standar atau alat pengukur yang disebut dengan Standar Operasional Prosedur (SOP). Standar Operasional Prosedur (SOP) Kementerian Agama Kota Sukabumi merupakan dasar dari peraturan-pertaturan. Standar Operasional Prosedur (SOP) Kementerian Agama Kota Sukabumi dibuat berdasarkan hasil evaluasi kinerja tahunan pegawai tahunan antara Kepala Seksi Penyelenggaraan Haji dan Umrah dengan bawahannya yang disetujui dan disahkan oleh Kepala Kementerian Agama Kota Sukabumi.

Berdasarkan hasil wawancara dengan bapak H. Dagus Surahman, S.Ag., selaku Kepala Seksi Penyelenggaraan Haji dan Umrah pada tanggal 12 Maret 2018, beliau memaparkan bahwa:

“.... Penetapan alat ukur ini dilakukan agar jemaah mendapatkan pelayanan prima, dan untuk pengawasannya disini kita pakai SOP, SOP itu kan dasarnya dari peraturan-peraturan, baik dari peraturan Kemnterian Agama, Peraturan Dirjen, dan peraturan Presiden, dan ntuk standar pengawasan itu memiliki indikator tertentu dan yang memiliki standar dari penyelenggaraan ibadah haji itu adalah BPS (Badan Pusat Statistik) karena di Seksi PHU ini ada lintas instansi, kita disini menyelenggarakan kegiatan ibadah haji itu ada SOP-nya, tapi kalau misalkan tolak ukurnya itu darimana? Tolak ukurnya itu dari BPS, karena BPS memiliki indikator dan penilaian sendiri terhadap penyelenggaraan ibadah haji” (wawancara pada hari Senin, 12 Maret 2018)

Tabel 1. Standar Operasional Prosedur Seleksi Petugas Haji

\begin{tabular}{c} 
Dasar Hukum \\
\hline Undang-undang Nomor 13 Tahun 2008 Tentang Penyelenggaraan Ibadah Haji \\
Undang-undang Nomor 34 Tahun 2009, Tentang penetapan perpu no. 2 tahun 2009 \\
PMA No. 15 tahun 2006 Tentang pendaftaran haji \\
Keterkaitan \\
KMA no 396 Tahun 2003, tentang perubahan KMA 371 tahun 2002 tentang \\
Penyelenggaraan Ibadah Haji \\
Peringatan \\
Apabila tidak dibuat SOP peraturan calon ibadah haji maka seleksi calon petugas haji tidak \\
maksimal
\end{tabular}


Administrasi tidak tertib disebabkan belum ada SOP

Sumber: SOP Seksi PHU Kemeterian Agama Kota Sukabumi

Menurut Handoko (2003:363) mengatakan bahwa ada tiga bentuk umum dari standar pengawasan, yaitu: 1) Standar-standar fisik, meliputi kuantitas barang atau jasa, jumlah pekerjaan atau kualitas pekerjaan. 2) Standar-standar moneter, yang ditunjukkan dalam rupiah dan mencakup biaya, biaya pekerjaan dan sejenisnya. 3) Standar-standar waktu, meliputi produksi atau batas waktu suatu pekerjaan harus diselesaikan. Dan untuk implementasi dari hasil teori tersebut bisa dilihat di table 1 SOP Seleksi petugas haji diatas sudah bisa dikatakan selaras dengan teori tersebut.

Maka dari itu dengan SOP inilah atasan dapat mengukur kinerja bawahannya apakah sudah bekerja dengan baik ataukah sebaliknya dan dengan SOP ini pula atasan dapat menilai apakah pelayanan yang diberikan oleh pegawai kepada jamaah ini sudah maksimal atau belum. Berdasarkan hasil wawancara dengan Kepala Seksi Penyelenggaraan Haji dan Umrah secara garis besar terdapat SOP diwilayah kerja Penyelenggaraan Haji dan Umrah di Kementerian Agama Kota Sukabumi. Melihat dari penentuan Standar Operasional Prosedur (SOP) ini, terlihat jelas bahwa Standar Operasional Prosedur (SOP) ini penting dilakukan untuk mencapai target yang akan dicapai, secara garis besar target dan tujuan yang ingin dicapai oleh Seksi Penyelenggaraan Haji dan Umrah ini yaitu untuk meningkatkan pelayanan kepada masyarakat tentang pelaksanaan haji dan umrah dan dari penetapan Standar Operasional Prosedur (SOP) ini nantinya dapat dijadikan ukuran atau pegangan terhadap pelaksanaan program kerja pada Seksi Penyelenggaraan Haji dan Umrah. Standar mengandung arti sebagai suatu satuan pengukuran yang digunakan sebagai patokan untuk menilai hasil-hasil. tujuan, sasaran, kuota, dan target digunakan sebagai standar Bentuk standar yang lebih khusus antara lain target penyelesaian pekerjaan, anggaran, keselamatan kerja dan sebagainya (Handoko, 2003:363).

\section{Evaluasi Pengawasan}

Fase kedua dalam proses pengawasan adalah menilai atau mengevaluasi. Maksudnya membandingkan hasil pekerjaan bawahan, dengan alat ukur (standar) yang sudah ditentukan. Pekerjaan bawahan dapat diketahui melalui berbagai cara, yakni dari laporan tertulis yang disusun bawahan, baik laporan rutin maupun laporan istimewa dan langsung mengunjungi bawahan untuk menanyakan hasil pekerjaannya atau bawahan dipanggil untuk memberi laporan lisan (Manullang, 2008:184)

Dalam proses pengawasan, seorang pemimpin harus memiliki berbagai cara untuk memastikan bahwa semua fungsi manajemen dilaksanakan dengan baik. Maka dari itu Kepala Seksi Penyelenggaraan Haji dan Umrah menggunakan metode-metode untuk membantu proses pengawasan, adapun metodenya yaitu:

Pertama, Pengawasan langsung adalah pengawasan yang dilakukan dengan cara mendatangi dan melakukan pemeriksaan di tempat (on the spot) terhadap 
objek yang akan diawasi. Menurut Soelistriyo (2003 : 86), Pengawasan langsung Adalah pengawasan yang dilaksanakan sendiri oleh atasan langsung, tanpa perantara. Kelebihan teknik langsung yaitu pimpinan mengetahui secara langsung yang terjadi di lapangan. Kekurangan teknik langsung yaitu sulit dilakukan dalam organisasi yang besar dan bersifat kompleks. Dalam hal ini pengawasan langsung yang dimaksud berupa pemeriksaan administratif atau pemeriksaan fisik di lapangan, yang dilakukan oleh kepala seksi penyelenggaraan haji dan umroh kepada bawahannya. Dan pemeriksaan langsung ke lapangan yang dilakukan oleh beliau ini yaitu untuk mengetahui secara langsung bagaimana kondisi kinerja yang dilakukan oleh pegawai, sehingga beliau dapat langsung mengetahui tentang apa saja yang dilakukan oleh pegawainya.

Kepala seksi penyelenggaraan haji dan umroh memeriksa pekerjaan yang sedang dilakukan, untuk mengetahui apakah dikerjakan dengan benar dan hasilhasilnya sesuai dengan yang dikehendaki. Pengawasan ini dimaksudkan agar tidak terjadi penyimpangan dalam pencapaian tujuan yang telah direncanakan sebelumnya. Oleh karena itu pengawasan ini dilakukan sebelum terjadinya penyimpangan-penyimpangan sehingga pengawasan ini bersifat preventif. Disamping itu dengan adanya pengawasan secara pribadi ini akan menumbuhkan hubungan tang harmonis antara pemimpin dengan bawahannya dan akan terbentuk kerjasama dan adanya rasa tanggung jawab terhadap pelaksanaan program kerja.

Kedua, Pengawasan Tidak Langsung merupakan pengawasan jarak jauh yang dimana dilakukan tanpa mendatangi tempat pelaksanaan pekerjaan atau objek yang diawasi. Menurut Soelistriyo (2003 : 86), Pengawasan tidak langsung Adalah pengawasan yang dilaksanakan dengan perantaraan sesuatu alat yang berwujud laporan, baik laporan lisan maupun tertulis. Kelebihan teknik tidak langsung adalah cocok untuk organisasi besar. Sedangkan kekurangannya adalah seringkali bawahan melaporkan hal-hal yang bersifat baik saja agar pimpinan senang, pimpinan tidak mengetahui keadaan yang sebenarnya terjadi. Dapat dikatakan pengawasan tidak langsung ini adalah pengawasan jarak jauh, dengan melalui laporan harian kinerja yang dilaporkan oleh bawahannya kepada pimpinan setiap bulannya. Adapun laporan yang dibuat oleh setiap pegawai mencakup tanggung jawabnya terhadap divisi masig-masing, tentang kegiatan apa saja yang sudah dikerjakan kaitannya dengan program kerja masing-masing divisi dan program apa saja yang sudah terlaksana maupun belum terlaksana.

Adapun tujuan dari pengawasan yang dilakukan oleh pimpinan kepada bawahannya adalah sebagai berikut: menertibkan koordinasi kegiatan-kegiatan, mencegah pemborosan dan penyelewengan, menjamin terwujudnya kepuasan masyarakat atas jasa yang dilakukan oleh pegawainya, membina kepercayaan masyarakat terhadap penyelenggaraan haji dan umroh di Kementrian Agama Kota Sukabumi. Ketika bentuk pengawasan pelaksanaan program kerja tersebut telah dilaksanakan, maka selanjutnya yang dilakukan oleh Kepala Seksi yaitu membandingkan tentang pelaksanaan kerja dengan standar kerja yang telah 
Syalsabila Ramadhini, Syamsuin RS, \& Asep Iwan Setiawan

ditentukan sebelumnya, setelah itu Kepala Seksi melakukan evaluasi untuk mengetahui sejauh mana pelaksanaan program kerja dan apakah terjadi kesalahan maupun penyimpangan pada saat pelaksanaan program kerja dan selanjutnya Kepala Seksi ini akan membantu dan memberikan saran apabila terjadi kesalahankesalahan pada saat pelaksanaan program kerja.

"......Setiap tahun kita melaksanakan evaluasi penyelenggaraan ibadah haji, dari evaluasi itu nanti dikumpulkan semua yang terlibat, dan membahas masalah yang terjadi seperti jamaah yang kedapatan memiliki penyakit jantung, dan ketika evaluasi nanti semuanya mengemukakan hasil kerja, dan evaluasi ini tidak dilakukan didaerah, tapi di provinsi dan biasanya dikumpulkan di salah satu hotel, dan nanti akan ada evaluasi, usulan, dan nantinya akan dibukukan hasil dari evaluasi tersebut....." (wawanacara pada hari Senin, 12 Maret 2018)

Berdasarkan hasil analisis penulis, tindakan evaluasi ini merupakan tahapan selanjutnya dalam proses pengawasan setelah penetapan standar, dimana setiap pemimpin membandingkan hasil pekerjaan bawahan, dengan alat ukur (standar) yang sudah ditentukan.. Adapun pelaksanaan evaluasi yang dilakukan oleh Kepala Seksi Penyelenggaraan Haji dan Umrah ini dilakukan pada saat: 1) secara berkala (tahunan), 2) Setiap minggu, 3) Setiap pelaksanaan kegiatan, 3) Apabila dianggap penting.

Adapun selain melaksanakan evaluasi, kepala seksi pun melakukan penilaian terhadap kinerja pegawainya, yang mana penilaian ini akan menjadi tolak ukur atas penetepan standar dengan pencapaian kinerja. Penilaian kinerja adalah suatu upaya untuk membandingkan kinerja yang harus dicapai dengan tujuan dan standar yang telah ditetapkan sebelumnya.

Penilaian kinerja dapat digunakan sebagai dasar kompetensi organisasional, sebagai dasar membuat perencanaan dan dapat memotret "kekurangan" dari kinerja organisasi secara keseluruhan, sehingga penilaian tersebut seharusnya dilakukan baik untuk karyawan maupun pimpinan. Penilaian kinerja merupakan sebuah proses yang berkelanjutan yang dilakukan secara terus menerus. Pengawasan ketika pelaksanaan program kerja, dilakukan dengan melalui proses pemerikasaan dan penilaian terhadap pelaksanaan program kerja yang sedang berlangsung. Menurut hasil wawancara dengan bapak H. Dagus Surahman, S.Ag., beliau mengatakan bahwa:

“....Kalau pegawai ini ada yang namanya SKP atau Sasaran Kerja Pegawai, tapi kalau kita disini ini masih mengerjakan dalam bentuk Excel terlebih dahulu namanya capaian kinerja harian, kalau SKP itu pertahun, sedangkan yang untuk harian itu ada yang namanya capaian kinerja harian, jadi misalnya saya itu dalam satu hari mengerjakan apa dan dalam satu bulan itu nanti ketahuan saya mengerjakan berapa pekrjaan dan hasil itu nanti dimasukan atau di upload lewat online dan nanti langsung diperiksa oleh Kasubag dan kepala kantor....” (wawancara pada hari Senin, 12 Maret 2018)

Pengawasan yang dilakukan pada Seksi Penyelenggaraan Haji dan Umrah 
ini mengacu pada peraturan PERDA tentang kebijakan negeri sipil yang dimana bahwa setiap pegawai atau yang memiliki jabatan fungsional itu harus mencatat dan melaporkan apa saja yang dikerjakan pada tiap hari kerja, dan berdasarkan PERDA tersebut maka beliau meminta kepada setiap pegawai agar selalu melaporkan tentang kegiatan yang dilakukan yang kaitannya dengan program kerja Seksi Penyelenggaraan Haji dan Umrah.

Berdasarkan hasil wawancara dengan Kepala Seksi Penyelenggaraan Haji dan Umrah penilaian kinerja pegawai dilaksanakan setiap satu tahun sekali namun pada realitas dilapangan proses penilaian kinerja juga dilakukan setiap harinya yang berupa Laporan Kinerja Harian $(\mathrm{LKH})$ pegawai yang nantinya direkapitulasi persatu tahunnya. Adapun hasil dari kinerja para pegawai itu nantinya akan diunduh di aplikasi dan web langsung setiap harinya untuk langsung diawasi oleh kasubag TU Kemenag Kota Sukabumi. Pada saat melaksanakan kinerja, pegawai wajib meminta acc atau moderasi dari Kepala Seksi tentang tugas apa yang dilakukan dan dikerjakan pada hari tersebut, karena bila tidak ada acc ataupun moderasi dari Kepala Seksi maka pekerjaan yang dilakukan oleh para pegawai tidak dihitung. Proses pengawasan kinerja pegawai ini akan dilakukan setiap bulannya agar mengetahui apakah kinerja pegawai itu menurun ataukah membaik. Dan seorang kepala seksi juga akan diberikan penilaian oleh Kepala Kantor Kementerian Agama Kota Sukabumi. Dalam pelaksanaan kinerja pegawai selain kinerja itu dinilai oleh kepala seksi langsung, namun kinerja juga dinilai oleh Badan Pusat Statistik (BPS) namun BPS ini memberikan penilaian pada saat penyelenggaraan haji dan penilaian ini dilakukan setahun sekali mengingat pelaksanaan penyelenggaraan haji ini dilakukan satu tahun sekali.

Penilaian kinerja merupakan proses mengevaluasi seberapa baik karyawan mengerjakan pekerjaan mereka ketika dibandingkan dengan satu set standar, dan kemudian mengomunikasikan informasi tersebut. Penilaian tersebut nantinya akan menjadi bahan masukan yang berarti dalam menilai kinerja yang dilakukan dan selanjutnya dapat dilakukan perbaikan, atau yang biasa disebut perbaikan yang berkelanjutan (Mathis dan Jackson, 2002:81)

\section{Tindakan Perbaikan (Corrective)}

Proses akhir dari pengawasan adalah tindakan perbaikan (corrective). Fase terakhir ini hanya dilaksanakan, bila pada fase sebelumnya dipastikan telah terjadi penyimpangan. Dengan tindakan perbaikan diartikan, tindakan yang diambil untuk menyesuaikan hasil pekerjaan nyata yang menyimpang agar sesuai dengan standar atau rencana yang telah ditentukan sebelumnya. Untuk dapat melaksanakan tindakan perbaikan, maka haruslah dianalisis apa yang menyebabkan terjadinya perbedaan itu (Manullang, 2008:184).

Seksi Penyelenggaraan Haji dan Umrah Kementerian Agama Kota Sukabumi dalam menerapkan pengawasan selain menetapkan standar yang dicapai, melakukan evaluasi atau penilaian terhadap kinerja pegawai juga melakukan tindakan perbaikan. Menurut Manulang (2008:185) tindakan perbaikan yaitu tindakan yang diambil untuk menyesuaikan hasil pekerjaan nyata yang 
menyimpang agar sesuai dengan standart atau rencana telah ditentukan sebelumnya. Tindakan perbaikan ini hanya dilaksanakan apabila pada saat pelaksanaan program kerja terjadi adanya penyimpangan, dengan demikian tindakan yang diambil untuk menyesuaikan hasil pekerjaan nyata yang menyinggung agar sesuai dengan standar atau program kerja yang telah ditentukan sebelumnya, dan untuk dapat melaksanakan tindakan perbiakan maka haruslah dianalisis terlebih dahulu apakah yang menyebabkan terjadinya kesalahan tersebut. Pada dasarnya tindakan perbaikan merupakan usaha untuk mengoreksi bentuk kesalahan pada saat pelaksanaan program kerja, yang dimana tindakan perbaikan ini akan berpengaruh terhadap peningkatan kinerja para pegawai agar target dan tujuan dapat tercapai, dan apabila diketahui adanya perbedaan dalam melakukan program kerja, atau melakukan penyimpangan maka langkah yang harus dilakukan oleh kepala seksi yaitu mengusahakan dan melaksanakan tindakan perbaikan sesegara mungkin.

Dari tindakan perbaikan ini kepala seksi dapat mengusahakan beberapa penyimpangan yang dapat langsung ditangani dengan cepat dan ada beberapa penyimpangan yang dapat diselesaikan dalam jangka waktu yang lama, dan untuk solusinya maka kepala seksi akan melakukan perbaikan dan dilaksanakan pada periode selanjutnya dengan cara kembali menyusun standar yang baru. Adapun tujuan dari tindakan perbaikan ini yaitu untuk memperbaiki jika terdapat kesalahan-kesalahan, agar tujuan dan standar yang telah ditentukan dapat tercapai dan pelaksanaan program kerja pada Seksi Penyelenggaraan Haji dan Umrah dapat berjalan dengan lancar dan maksimal.

Pada saat melakukan tindakan perbaikan kepala seksi akan selalu mengawasi kinerja setiap bawahannya karena dengan begitu akan lebih terlihat ketika seorang pegawai melakukan penyimpangan-penyimpangan pada saat melakukan pekerjaan, dan ketika seorang pegawai melakukan penyimpangan maka kepala seksi akan langsung turun tangan dalam memperbaiki penyimpangan tersebut. Menurut hasil wawancara dengan bapak Dr. H. Ade Hendra Guna, M.Pd selaku pegawai bagian Penyusunan Perlengkapan Haji pada tanggal 12 Maret 2018, beliau mengatakan bahwa:

"....tindakan yang dilakukan oleh kasi disini bila ada pegawai yang melakukan kesalahan yaitu yang pertama, pegawai tersebut dipanggil dan di introgasi tentang kesalahannya, malah kepempinan kasi disini katakanlah bagus karena selalu memecahkan permasalahan yang dihadapi oleh pegawai, jadi ketika kami melakukan kesalahan kami laporan kepada kasi dan kasi akan memberikan solusi kepada kami untuk melaksanakan kinerja yang lebih baik lagi"

Tindakan perbaikan yang dilakukan oleh kepala seksi itu sangat diapresiasi sekali oleh para pegawai karena kepala seksi selalu melakukan konsultasi dengan para pegawai jika ada pegawai yang melakukan tindakan kesalahan dan kepala seksi juga selalu membantu dalam memecahkan permasalahan yang terjadi sehingga pegawai lebih mengerti tentang apa yang harus dilakukan dalam meminimalisir 
kesalahan atau penyimpangan dan menurut beliau juga kepala seksi selalu turun tangan dalam membantu mengerjakan tugas-tugas yang terdapat kesalahan didalamnya. Maka dari itu, usaha yang dilakukan oleh Kepala Seksi Penyelenggaraan Haji dan Umrah adalah sebagai berikut:

Pertama, Pengecekan langsung ke lapangan untuk mengetahui kinerja pegawai, metode ini sangat ampuh untuk dilakukan ketika melakukan pengawasan, karena dengan metode ini kepala seksi akan lebih mengetahui bagaimana keadaan lapangan pada saat pegawai melaksanakan program kerja, dengan metode ini juga dapat menumbuhkan kedekatan yang harmonis antara pegawai dengan atasannya.

Kedua, Meningkatkan pengawasan dengan tujuan untuk meningkatkan kinerja pegawai, dalam upaya meningkatkan kinerja pegawai dalam mencapai tujuan yang telah ditetapkan, kepala seksi akan meningkatkan pengawasan baik pengawasan secara langsung maupun tidak langsung. Karena dengan cara ini kepala seksi dapat meminimalisir adanya penyimpangan-penyimpangan yang mungkin akan terjadi pada saat pelaksanaan program kerja.

Ketiga, Mengadakan rapat-rapat internal antara pemimpin dan pegawai yang isinya membahas tentang pelaksanaan prorgam kerja yang akan dijalankan kedepannya, selain dengan melakukan pengawasan langsung dengan cara terjun langsung ke lapangan, kepala seksi pun melakukan evaluasi dan tindakan perbaikan dengan cara mengadakan rapat-rapat internal dimana di dalam rapat ini kepala seksi akan menggali informasi tentang pelaksanaan program kerja langsung kepada pegawai, dan dengan rapat ini kepala seksi akan langsung memberikan solusi-solusi langsung kepada para pegawai jika terdapat kesalahan-kesalan baik itu kesalahan yang dapat langsung diminimalisir dengan cepat ataupun kesalahan yang dapat diminimalisir dalam jangka waktu lama.

Berdasarkan hasil analisa penulis, tindakan perbaikan yang dilakukan oleh Kepala Seksi Penyelenggaraan Haji dan Umrah ini telah sesuai dengan pola pengawasan yang efektif pada suatu lembaga organisasi. Karena tujuan dari pengawasan sendiri yaitu untuk memperbaiki kesalahan-kesalahan yang dibuat oleh pegawai dan pimpinan harus selalu mengusahakan pencegahan agar nantinya tidak terdapat lagi kesalahan-kesalahan yang baru. Berdasarkan hasil wawancara yang dilakukan oleh penulis dengan bapak H. Dagus Surahman, S.Ag., beliau mengatakan bahwa pelaksanaan program kerja di Seksi Penyelenggaraan Haji dan Umrah dapat terlaksana dengan baik dan sesuai dengan tujuan yang ingin dicapai serta tanpa kesalahan-kesalahan yang begitu berarti.

Menurut T. Hani Handoko (2003:365), tindakan koreksi dapat dilakukan dengan: 1) Mengubah standar mula-mula (barangkali terlalu tinggi atau terlalu rendah. 2) Mengubah pengukuran pelaksanaan (inspeksi terlalu sering frekuensinya atau kurang atau bahkan mengganti sistem pengukuran). 3) Mengubah cara menganalisa dan menginterpretasikan penyimpangan penyimpangan. 


\section{PENUTUP}

Berdasarkan temuan dari penelitian yang telah dilaksanakan dan dibahas pada bab-bab sebelumnya, penulis dapat mengambil kesimpulan dari masalah yang penulis bahas yaitu tentang pola pengawasan kepala Seksi Penyelenggaraan Haji dan Umrah dalam meningkatkan kinerja pegawai, berdasarkan data yang penulis peroleh maka dapat di ambil kesimpulan sebagai berikut:

Pertama, dalam melaksanakan pengawasan terhadap program keja, Kepala Seksi Penyelenggaran Haji dan Umrah menggunakan metode-metode dalam membantu proses pengawasan yang meana meliputi: (a) Pengawasan Langsung, pada proses pengawasan ini kepala seksi akan langsung terjun langsung dalam mengawasi kinerja para pegawainya, sebagaimana yang dibahas dalam hasil wawancara langsung dengan kepala seksi Penyelenggaraan Haji dan Umrah bahwa bentuk pengawasan ini bersifat kondisional atau tidak menentu waktunya. Karena pengawasan ini dilakukan sesuai kebutuhan. (b) Pengawasan Tidak Langsung, pengawasan tidak langsung merupakan pengawasan jarak jauh yang dimana dilakukan tanpa mendatangi tempat pelaksanaan pekerjaan ata objek yang diawasi. Jadi Kepala Seksi Penyelenggaraan Haji dan Umrah melakukan pengawasan melalui proses pemeriksaan dan penilaian terhadap laporan kinerja harian sesuai dengan aturan PERDA.

Kedua, penilaian kinerja pegawai dilaksanakan setiap satu tahun sekali namun pada realitas dilapangan proses penilaian kinerja juga dilakukan setiap harinya yang berupa Laporan Kinerja Harian $(\mathrm{LKH})$ pegawai yang nantinya direkapitulasi persatu tahunnya. Adapun hasil dari kinerja para pegawai itu nantinya akan diunduh di aplikasi dan web langsung setiap harinya untuk langsung diawasi oleh kasubag TU Kemenag Kota Sukabumi.

Ketiga, seksi Penyelenggaraan Haji dan Umrah Kementerian Agama Kota Sukabumi dalam menerapkan pengawasan selain menetapkan standar yang dicapai, melakukan evaluasi atau penilaian terhadap kinerja pegawai juga melakukan tindakan perbaikan. Maka dari itu, usaha yang dilakukan oleh Kepala Seksi Penyelenggaraan Haji dan Umrah adalah sebagai berikut: (a) Pengecekan langsung ke lapangan untuk mengetahui kinerja pegawai. (b) Meningkatkan pengawsan dengan tujuan untuk meningkatkan kinerja pegawai (c) Mengadakan rapat-rapat internal antara pemimin dan pegawai yang isinya membahas tentang pelaksanaan prorgam kerja yang akan dijalankan kedepannya.

Berdasarkan hasil dari pemaparan kesimpulan di atas, maka penulis akan memberikan sedikit saran terkait pengawasan yang dilakukan oleh kepala seksi Penyelenggaraan Haji dan Umrah dalam upaya meningkatkan kinerja pegawainya, yaitu: 1) Pengawasan merupakan suatu cara agar pemimpin dapat mengetahui kinerja pegawai setiap harinya, maka dari itu diharapkan kepala seksi Penyelenggaraan Haji dan Umrah dapat lebih meningkatkan evektifitas pengawasan terhadap pegawainya agar tidak terjadi penyimpangan-penyimpangan 
Pola Pengawasan Kepala Seksi Penyelenggaraan Haji dan Umrah dalam Meningkatkan Kinerja Pegawai

yang berarti pada saat proses pengerjaan program kerja serta diharapkan dengan adanya pengawasan ini pegawai menjadi lebih dekat dengan atasannya dan pegawai bukan merasa terintimidasi karena merasa pekerjaannya diawasi. 2) Tujuan dari lembaga itu harus dapat di capai bersama, maka dari itu pemimpin harus bisa memberikan motivasi kepada pegawainya agar pegawai merasa nyaman dan merasa semangat agar tujuan yang telah ditentukan bersama dapat terlaksana dengan lancar dan sesuai dengan yang diharapkan.

\section{DAFTAR PUSTAKA}

Handoko, T. H. (2003). Manajemen, Cetakan Kedelapan Belas. Yogyakarta: BPFE Yogyakarta.

Hasibuan, M. S. (2004). Manajemen Sumber Daya Manusia. Jakarta: Bumi Aksara. Hasibuan, M. S. (2011). Manajemen Dasar, Pengertian, dan Masalah. Jakarta: Bumi Aksara.

Kusnawan, A. (2015). Konsep Manajemen Pelatihan Dakwah. Ilmu Dakwah: Academic Journal For Homiletic Studies, 4(12), 335-370.

Lilis, S. (2016). Sumber Daya Manusia Strategik. Bandung: La Good's Publishing.

Manulang. M. (1981). Manajemen Personalia. Jakarta Timur: Yudistira.

Manullang, M. (2008). Dasar-Dasar Manajemen. Yogyakarta: Gadjah Mada University Press.

Sukayat, T. (2016). Manajemen Haji, Umrah dan Wisata Agama. Bandung: Simbiosa Rekatama Media.

Soelistriyo (2003). Buku Ajar Pengantar Manajemen. Bandung: Alfabeta

Syari'ati, A. (2000). Haji. Bandung: Pustaka. 